\title{
GENETSKA KARAKTERIZACIJA EUROPSKE CRNE TOPOLE (Populus nigra L.) U BOSNI I HERCEGOVINI
}

\section{Genetic characterization of European black poplar}

\author{
(Populus nigra L.) in Bosnia and Herzegovina
}

Dalibor BALLIAN ${ }^{1,2}$, Ute TRÖBER

\begin{abstract}
Sažetak
Europska crna topola (Populus nigra L.) u Europi predstavlja jednu od ekološki najznačajnijih vrsta šumskog drveća ritskih šuma, a u nekim zemljama ona je i od gospodarskog značenja. U Bosni i Hercegovini, uz europsku crnu topolu raste i dlakava crna topola (Populus nigra subsp.caudina). Ovoj vrsti nije se u prošlosti poklanjao značajan interes, dok se danas intenzivno radi na njezinom očuvanju i revitalizaciji prirodnih sastojina, iako ima zemalja gdje je i dalje marginalizirana.

U Bosni i Hercegovini postoji dobar potencijal za osnivanje topolovih šuma, a prema posljednjoj inventuri raspolaže se s površinom od oko 40000 ha gdje mogu rasti topole, u malim čistim sastojinama ili većinom u mješovitim sastojinama s vrbom i drugim hidrofilnim vrstama drveća.

Za molekularnu analizu koristili smo deset mikrosatelitskih početnica, odnosno analizirali smo deset genskih lokusa, s ukupno 422 alela u svim istraživanim populacijama, a sadržavali su 17 specifičnih alela.

Broj alela po genskim lokusima za istraživane populacije kretao se od 1 do 17. Stvarna i teorijska heterozigotnost bila je najniža u populaciji Neretva, dok je najveća vrijednost bila u populaciji gornjeg toka Bosne. Fiksacijski indeks u svim populacijama bio je pozitivan i blizu nule, što ukazuje na dobru stabilnost istraživanih populacija, osim kod populacije Neretva, gdje su više vrijednosti upućivale na prisutnost inbridinga. Najveću genetsku diferencijaciju uz odsutnost protoka gena također pokazuje populacija Neretve, za razliku od ostalih istraživanih populacija.

Dobiveni rezultati omogućuju preporuku potrebnih mjera za očuvanje genetskih izvora, te obnovu i uporabu klonskog šumskog reprodukcijskog materijala crnih topola u Bosni i Hercegovini.
\end{abstract}

KLJUČNERIJEČI: Europska crna topola, Populus nigra subsp. caudina, genetska varijabilnost, Bosna i Hercegovina

\section{UVOD}

\section{INTRODUCTION}

Europska crna topola (Populus nigraL.), ima široko područje rasprostranjenja od Mediterana na jugu do $64^{\circ}$ zemljopisne geografske širine na sjever, te od Britanskog otočja do zapadne Azije (Zsuffa 1974). To je pionirska vrsta drveća iz riječnih ekosustava, strogo heliofilna vrsta i stvara metapopulacije kolonizacijom otvorenih prostora, bilo sjemenom ili vegetativno reznicama i korijenjacima (Zsuffa 1974; Herpka 1986; Pospišková i Bartáková 2004; De Woody 2011; Čortan i sur. 2015). U Europi i svijetu crne topole predstavljaju jedne od ekološki najznačajnijih vrsta šum-

\footnotetext{
1.2Prof. dr. sc. Dalibor Ballian, Šumarski fakultet Univerziteta u Sarajevu, Zagrebačka 20, 71000 Sarajevo, Bosna i Hercegovina, balliandalibor9@gmail.com; ${ }^{2}$ Gozdarski inštitut Slovenije, Večna pot 2, 1000 Ljubljana, Slovenia

${ }^{3}$ Ute Tröber, Staaetsbetrieb, Bonnewitzer Straße 34 D-01796 Pirna OT Graupa, Deutschland
} 
skog drveća s ekološkog, a djelomično i s gospodarskog gledišta, ali je u Bosni i Hercegovini, kao i mnogim zemljama središnje Europe europska crna topola marginalizirana.

Prema posljednjoj inventuri šuma u Bosni i Hercegovini, ukupna površina šuma i šumskih zemljišta iznosi 3.231 .500 ha, od čega na visoke šume otpada 1.652 .400 ha, na niske šume 1.252.200 ha i šikare 130.600 ha, te na goleti 187.200 ha (Lojo i Balić 2011). Prirodne šume topola nalaze se na oko 900 ha, a plantaže euroameričkih topola su na površini od oko 100 ha, s tim da postoje brojne manje grupe stabala crnih topola duž vodotoka, kao i mnoge kulture u južnom i jugozapadnom dijelu zemlje. Ipak prema novoj inventuri, šume Bosne i Hercegovine imaju potencijal od 40.000 ha područja pogodnog za uzgoj šuma vrba i topola, pretežito u ravničarskom dijelu zemlje, odnosno Posavini (Lojo i Balić 2011). Topole u Bosni i Hercegovini nalazimo na aluvijalnim, rahlim pjeskovitim zemljištima duž rijeka, ravničarskih i nižih brdskih područja, do oko 300 m n. v. (Šilić 1983; Ballian 2004), iako u unutrašnjosti u dolinama rastu i do $700 \mathrm{~m}$ n.v.. Trenutno se s ovako malim površinama topola u Bosni i Hercegovini ne može pretendirati na neku veću proizvodnju, kao što je to slučaj u velikim i visokorazvijenim zemljama. Ipak prednost Bosne i Hercegovine je u njenom autoktonom genofondu, za koji možemo reći da je jedan od najbolje očuvanih u Europi. Kako su staništa europske crne topole ograničena samo na doline većih rijeka, te ih nalazimo na obalama Drine, Bosne, Lašve, Ukrine, Spreče, Vrbasa, Une, Sane i Neretve, kao i nekih manjih njihovih pritoka (Ballian 2004). U Bosni i Hercegovini nalazimo četiri osnovne vrste topola te uz europske crne topole (Populus nigraL.) nalazimo bijelu topolu (P. albaL.), trepetljiku (P. tremulaL.) i sivu topolu $(P . \times$ canescens (Aiton) Sm.), kao i čitav spektar nižih taksona koji proizlaze iz ove četiri vrste (Back-Mannagetta 1906; Fukarek 1959; Janjić 1983,1984,1990,1992-1996). Možda najviše pozornosti od nižih taksona treba obratiti takozvanim dlakavim crnim topolama (Populus nigra subsp. caudina), koje rastu u jugozapadnom području Bosne i Hercegovine, uz rijeku Neretvu (Janjić 1984; Jovanović 2000; Ballian 2004; Kajba i sur. 2004; 2015; De Woody 2011).

Kada su krajem 18. stoljeća iz sjeverne Amerike u Europu (Francusku) prenesene crne topole, počele su spontana križanjas europskim crnim topolama. Nastali su različiti hibridi, koji su posebice u zapadnoj i srednjoj Europi počeli potiskivati autohtonu crnu topolu (Ballian i Mikić 1999). Tako se područje rasprostiranja crnih topola smanjivalo, pod utjecajem čovjeka, bilo sječom ili posredno promjenama ekoloških uvjeta. Tako se u mnogim europskim zemljama crne topole smatraju vrstom u nestajanju, zbog stalne kontaminacije prirodnih staništa hibridima, te njihovim širenjem na račun njihovog staništa djelovanjem čovjeka (Heinze 1998a; 1998b). U mnogim zemljama, posebice Italiji, u cilju očuvanja genofonda ove vrste pristupilo se pronalaženju i reintroduciranju autohtonih crnih topola. Da bi se izbjegla reintroduciranje hibrida, bilo je potrebno pronaći što starija stabla izvan područja sa plantažama hibridnih topola, kako bi genofond bio potpuno autohtoni. Posebnu pozornost u Italiji (Bisoffi i sur. 1987) usmjerili su i na očuvanje odnosa između spolova, kako bi se što bolje očuvala genetička struktura autohtone vrste crne topole.

Prva introdukcija alohtonih vrsta topola, većinom hibrida, vezuje se za dolazak Austrougarske monarhije u Bosnu i Hercegovinu (Ballian i Mikić 1999). Tada se uz željezničke postaje sade prve hibridne topole, te neke od egzotičnih vrsta. Ipak nije došlo do veće introgresije alohtonih gena u prirodne populacije, te autohtoni genofond crnih topola predstavlja pravu riznicu. Za takvo stanje ponajprije trebamo zahvaliti činjenici da u Bosni i Hercegovini nikad nije u velikoj mjeri počela intenzivna proizvodnja mekih listača, nego su se njihove potrebe podmirivale uvozom iz susjednih zemalja. Ipak je bilo pokušaja da se osnuju određene površine plantaža, ali su rezultati bili bez većeg uspjeha, jer ih je pratio slab prinos i pojave patogena. Tako još i danas možemo u Bosni naići na te plantaže. U novije vrijeme počinje se razmišljati o rješavanju problema proizvodnje biomase, koja bi trebala odigrati vrlo bitnu ulogu u stvaranju energetskog potencijala, te će u tom segmentu autohtone crne topole igrati vrlo važnu ulogu kroz podizanje intenzivnih ili ekstenzivnih nasada. Tako bi se ujedno smanjila mogućnost pojave introgresije alohtonih gena, te i dalje očuvala dobra genetička osnova autohtonih topola.

Za sada osnovnu prijetnju autohtonom genofondu predstavlja neplansko korištenje zemljišta i stihijska regulacija riječnih tokova, otvaranje šljunčara, deponiranje otpadnoga materijala, kao i nepostojanje nikakve zakonske regulative koja bi zaštitila stanje sadašnjeg genofonda crnih topola (Ballian 2004).

Na zaštiti autohtonog genofonda topola je puno toga napravljeno. Na temelju iskustava kolega iz Hrvatske tijekom 2006. godine prišlo se osnivanju klonskog arhiva crnih topola, koji sadrži 163 klona selekcionirana u autohtonim populacijama crnih topola u Bosni i Hercegovini (Ballian i Mekić 2008a; 2008b; Ballian 2009). Prilikom osnivanja klonskog arhiva u Žepču selekcioniran je materijal autohtonih crnih topola prema uputama koja su dane od strane EUFORGEN-a (Vanden Broeck 2003), a selekcionirana su samo stara stabla, starosti preko 80 godina, kako bi se izbjegla kontaminacija alohtonim genofondom. Uz aktivnosti na zaštiti u tijeku su već duži niz godina i radovi na istraživanju unutarpopulacijske i međupopulacijske varijabilnosti na morfološkoj razini (Kajba i sur. 2004;Kajba i sur. 2015; Ballian i sur. 2006; De Woody 2011).

Cilj ovoga rada je upotpuniti poznavanje genetske strukture crnih topola u Bosni i Hercegovini na temelju DNK analiza. Također ovim istraživanjem će se odrediti molekularno genetska povezanost populacija crnih topola u Bosni i Her- 
Tablica 1. Podaci o istraživanim populacijama

Table 1. List of investigated populations

\begin{tabular}{|c|c|c|c|c|c|}
\hline $\begin{array}{l}\text { Rijeka } \\
\text { River }\end{array}$ & $\begin{array}{l}\text { Lokalitet } \\
\text { Locality }\end{array}$ & $\begin{array}{l}\text { Zemljopisna } \\
\text { dužina } \\
\text { Longitude }\end{array}$ & $\begin{array}{l}\text { Zemljopisna } \\
\text { širina } \\
\text { Latitude }\end{array}$ & $\begin{array}{l}\text { Nadmorska } \\
\text { visina }(\mathrm{m}) \\
\text { altitude }(\mathrm{m})\end{array}$ & $\begin{array}{c}\text { Broj uspješno } \\
\text { analiziranih biljaka } \\
\text { Number of successfully } \\
\text { analyzed trees }\end{array}$ \\
\hline Neretva gornji tok & Konjic & $43^{\circ} 40^{\prime} 11^{\prime \prime}$ & $17^{\circ} 58^{\prime} 36^{\prime \prime}$ & 341 & 9 \\
\hline Neretva donji tok & Čapljina & $43^{\circ} 08^{\prime} 41^{\prime \prime}$ & $17^{\circ} 43^{\prime} 47^{\prime \prime}$ & 36 & 14 \\
\hline \multirow{6}{*}{ Bosna gornji tok } & Sarajevo & $43^{\circ} 51^{\prime} 20^{\prime \prime}$ & $18^{\circ} 24^{\prime} 08^{\prime \prime}$ & 539 & 3 \\
\hline & Ilidža & $43^{\circ} 49^{\prime} 16^{\prime \prime}$ & $18^{\circ} 17^{\prime} 57^{\prime \prime}$ & 496 & 1 \\
\hline & Visoko & $43^{\circ} 59^{\prime} 27^{\prime \prime}$ & $18^{\circ} 10^{\prime} 56^{\prime \prime}$ & 422 & 4 \\
\hline & Dobrinje & $44^{\circ} 07^{\prime} 13^{\prime \prime}$ & $18^{\circ} 06^{\prime} 36^{\prime \prime}$ & 375 & 1 \\
\hline & Rudnik & $44^{\circ} 08^{\prime} 10^{\prime \prime}$ & $18^{\circ} 03^{\prime} 40^{\prime \prime}$ & 410 & 3 \\
\hline & Bilješevo & $44^{\circ} 07^{\prime} 57^{\prime \prime}$ & $17^{\circ} 59^{\prime} 48^{\prime \prime}$ & 362 & 8 \\
\hline \multirow{2}{*}{ Bosna srednji tok } & Babina rijeka & $44^{\circ} 11^{\prime} 55^{\prime \prime}$ & $17^{\circ} 55^{\prime} 30^{\prime \prime}$ & 345 & 6 \\
\hline & Zenica & $44^{\circ} 12^{\prime} 12^{\prime \prime}$ & $17^{\circ} 54^{\prime} 43^{\prime \prime}$ & 315 & 4 \\
\hline \multirow{2}{*}{ Bosna donji tok } & Maglaj & $44^{\circ} 34^{\prime} 24^{\prime \prime}$ & $18^{\circ} 06^{\prime} 10^{\prime \prime}$ & 201 & 3 \\
\hline & Doboj & $44^{\circ} 44^{\prime} 24^{\prime \prime}$ & $18^{\circ} 05^{\prime} 55^{\prime \prime}$ & 137 & 11 \\
\hline Lašva uključena u srednji tok Bosne & Travnik & $44^{\circ} 13^{\prime} 08^{\prime \prime}$ & $17^{\circ} 41^{\prime} 30^{\prime \prime}$ & 476 & 4 \\
\hline Vrbas gornji tok & Bugojno & $44^{\circ} 00^{\prime} 57^{\prime \prime}$ & $17^{\circ} 29^{\prime} 14^{\prime \prime}$ & 600 & 7 \\
\hline \multirow{3}{*}{ Vrbas srednji tok } & Jajce & $44^{\circ} 18^{\prime} 58^{\prime \prime}$ & $17^{\circ} 14^{\prime} 48^{\prime \prime}$ & 389 & 2 \\
\hline & Podmilačje & $44^{\circ} 21^{\prime} 59^{\prime \prime}$ & $17^{\circ} 17^{\prime} 48^{\prime \prime}$ & 351 & 4 \\
\hline & Krupa & $44^{\circ} 36^{\prime} 52^{\prime \prime}$ & $17^{\circ} 08^{\prime} 55^{\prime \prime}$ & 211 & 4 \\
\hline \multirow{2}{*}{ Vrbas donji tok } & Toplice & $44^{\circ} 44^{\prime} 18^{\prime \prime}$ & $17^{\circ} 09^{\prime} 17^{\prime \prime}$ & 170 & 5 \\
\hline & Banja luka & $44^{\circ} 46^{\prime} 09^{\prime \prime}$ & $17^{\circ} 13^{\prime} 05^{\prime \prime}$ & 152 & 10 \\
\hline \multirow{2}{*}{ Drina gornji tok } & Osanica & $43^{\circ} 36^{\prime} 36^{\prime \prime}$ & $18^{\circ} 52^{\prime} 07^{\prime \prime}$ & 359 & 6 \\
\hline & Kopači & $43^{\circ} 40^{\prime} 26^{\prime \prime}$ & $19^{\circ} 02^{\prime} 01^{\prime \prime}$ & 348 & 8 \\
\hline \multirow{2}{*}{ Drina donji tok } & Tegare & $44^{\circ} 06^{\prime} 53^{\prime \prime}$ & $19^{\circ} 29^{\prime} 20^{\prime \prime}$ & 187 & 10 \\
\hline & Bratunac & $44^{\circ} 10^{\prime} 08^{\prime \prime}$ & $19^{\circ} 23^{\prime} 57^{\prime \prime}$ & 173 & 1 \\
\hline \multirow{3}{*}{ Spreča } & Lukavac & $44^{\circ} 33^{\prime} 15^{\prime \prime}$ & $18^{\circ} 28^{\prime} 44^{\prime \prime}$ & 175 & 5 \\
\hline & Gračanica & $44^{\circ} 40^{\prime} 40^{\prime \prime}$ & $18^{\circ} 18^{\prime} 13^{\prime \prime}$ & 154 & 2 \\
\hline & Velika Brijesnica & $44^{\circ} 43^{\prime} 28^{\prime \prime}$ & $18^{\circ} 10^{\prime} 23^{\prime \prime}$ & 144 & 1 \\
\hline
\end{tabular}

cegovini duž riječnih vodotoka. Kroz ovo istraživanje želimo odgovoriti na sljedeće pitanje: kakva je genetska struktura, raznolikost i diferencijacija populacija crne topole iz riječnih sljevova u Bosni i Hercegovini, te kakvo je značenje poznavanja genetičke strukture u procesima obnove i očuvanja ove vrste?

Uz fundamentalno značenje ovog istraživanja, ono je također primjenljivo u budućem gospodarenju crnim topolama, jer će dati bolju genetsku sliku, a što je od važnosti za daljnje radove na njegovom oplemenjivanju, odnosno kod kontrole podrijetla šumskog reprodukcijskog materijala bitnog za proces umjetne obnove degradiranih riječnih staništa, kao i za poslove vezane na identificiranju klonova u arhivu crnih topola u Žepču.

\section{MATERIJAL I METODE RADA MATERIAL AND METHODS}

Tijekom rujna 2014. godine sabran je biljni materijal u klonskom arhivu crnih topola u Žepču (Ballian i Mekić 2008a;Ballian i Mekić 2008b; Ballian 2009). Sabrani su ze- leni listovi, sa 141 klona, čije su ortete bile starije od 80 godina, a podrijetlom su iz 26 populacija (Tablica 1., Slika 1), koji su nakon sabiranja pohranjeni u silica gel do ekstrakcije DNK, tijekom analiza determinirani su hibridi nastali povratnom hibridizacijom s euroameričkim hibridima, te smo ih isključili iz analize, dok je uspješno analizirano ukupno 136 individua $(\mathrm{N})$.

Za ekstrakciju DNK iz suhog biljnog materijala uporabljen je Innupure C16 and innuPREP Plant DNA Kit-IP-C16 proizvođača Analytik Jena, a provjera ekstrakcije obavljena je na agarnom gelu od 2\%. Za amplifikaciju su korištene mikrosatelitne početnice za topole koje su dane u tablici 2, a koje su ranije uspješno uporabljene u sličnim istraživanjima (Cremer i Konnert 2010; Tröber i Wolf 2015), a to će omogućiti širu uporabu rezultata u budućnosti. Uključene su i neke od od početnica koje daju specifične alele i osiguravaju karakterizaciju Populus nigra i P. Deltoides, odnosno njihovih hibrida (Ziegenhagen i sur. 2008; Rathmacher i sur. 2009).

Za lančanu reakciju polimerazom uporabljene su tri višestruke reakcije uz Qiagen Type-it Multiplex Kit sa tempera- 


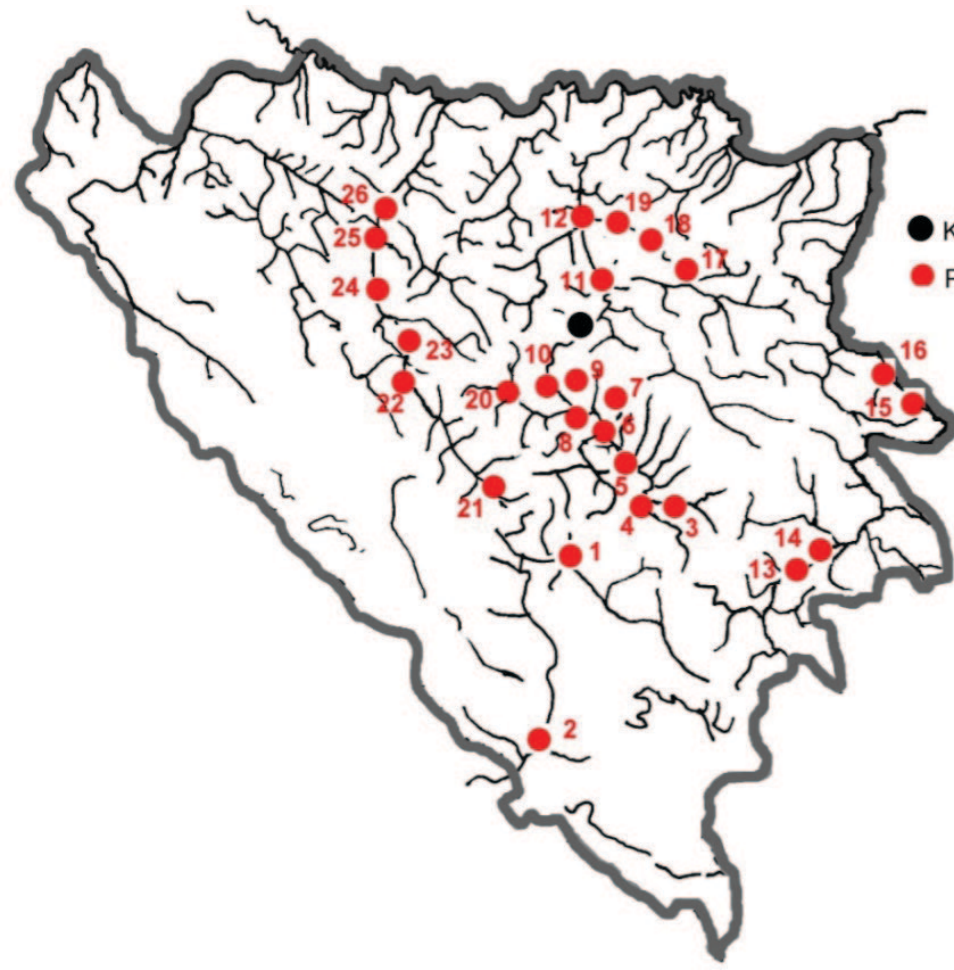

Klonski arhiv Žepče

Pozicije arhiviranih populacija

turom nalijeganja od $57^{\circ} \mathrm{C}$, uz ukupno 28 krugova u termokrugu.

Za analizu produkata dobivenih lančanom reakcijom polimerazom uporabljen je CEQ 8000 kapilarni elektroforetski sustav (Fa. Beckman-Coulter). Za statističku analizu korišten je softver CONVERT (Glaubitz 2004) and GDA_NT (Degen 2008), STRUCTURE 2.2 (Pritcharda i sur. 2007) i GeneAlEx (Peakall i Smouse 2012), a za samu analizu grupirali smo populacije prema odvojenim dijelovima rječnih slivova, dok smo populacije rijeke Bosne podijelili na gornji, srednji i donji tok (Tablica 1).

\section{REZULTATI RESULTS}

Slika 1. Istraživani lokaliteti populacija crnih topola: 1 Konjic, 2 Čapljina, 3 Sarajevo, 4 Ilidža, 5 Visoko, 6 Kakanj, 7 Rudnik, 8 Bilješevo, 9 Babina Rijeka, 10 Zenica, 11 Maglaj, 12 Doboj, 13 Osanica, 14 Kopači, 15 Tegare, 16 Bratunac, 17 Lukavac, 18 Gračanica, 19 Velika Brijesnica, 20 Travnik, 21 Bugojno, 22 Jajce, 23 Podmilačje, 24 Krupa, 25 Toplica, 26 Banja Luka.

Figure 1. Investigated localities of black poplar: 1 Konjic, 2 Čapljina, 3 Sarajevo, 4 llidža, 5 Visoko, 6 Kakanj, 7 Rudnik, 8 Bilješevo, 9 Babina Rijeka, 10Zenica, 11 Maglaj, 12 Doboj, 13 Osanica, 14 Kopači, 15 Tegare, 16 Bratunac, 17 Lukavac, 18 Gračanica, 19 Velika Brijesnica, 20 Travnik, 21 Bugojno, 22 Jajce, 23 Podmilačje, 24 Krupa, 25 Toplica, 26 Banja Luka.

Uporabom deset mikrosatelitskih biljega analiziran je polimorfizam u šest riječnih slivova, gdje su za analizu uporabljena stara stabla autohtonih crnih topola (Tablica 3.). Nakon uspješno urađenoga sekvencioniranja amplificiranih uzoraka iz analiziranih populacija i statističke obrade podataka, kao rezultat mikrosatelitske analize dobiveno je ukupno 422 alela u svim istraživanim populacijama (Tablica 1. i3.). Rezultati pokazuju da u istraživanim populacijama postoji velika polimorfnost, odnosno velika genetička razno-

Tablica 2: Uporabljene početnice i potrebne koncentracije za višestruku PCR reakciju

Table 2. The used primers and the necessary concentration for multiple PCR reaction

\begin{tabular}{|c|c|c|c|c|c|c|c|}
\hline $\begin{array}{l}\text { Početnica } \\
\text { (Genski lokus) } \\
\text { Primer }\end{array}$ & $\begin{array}{l}\text { Referenca } \\
\text { Reference }\end{array}$ & $\begin{array}{c}\text { Oznaka biljega } \\
\text { Marker }\end{array}$ & $\begin{array}{l}\text { Alelni raspon } \\
\text { u pb } \\
\text { Allelic range } \\
\text { in bp }\end{array}$ & $\begin{array}{l}\text { Broj } \\
\text { alela } \\
\text { Number } \\
\text { of allel }\end{array}$ & Multiplex & Koncent. & $\begin{array}{l}\text { Specifični } \\
\text { Aleli* }^{*} \\
\text { Specific } \\
\text { alleles* }^{*}\end{array}$ \\
\hline PMGC_14 & IPGC & Cy5 & $202-226$ & 9 & 1 & $2 \mu \mathrm{M}$ & 2 \\
\hline WPMS_18 & Smulders i sur. 2001 & BMN-6 & $226-253$ & 9 & 1 & $2 \mu \mathrm{M}$ & 1 \\
\hline WPMS_09 & van der Schoot i sur. 2000 & DY-751 & $246-306$ & 18 & 1 & $2 \mu \mathrm{M}$ & 1 \\
\hline PMGC_2163 & IPGC & Cy5 & $220-258$ & 18 & 2 & $2 \mu \mathrm{M}$ & 1 \\
\hline WPMS_14 & Smulders i sur. 2001 & BMN-6 & $228-279$ & 12 & 2 & $2 \mu \mathrm{M}$ & \\
\hline WPMS_12 & van der Schoot i sur. 2000 & DY-751 & $159-179$ & 10 & 2 & $2 \mu \mathrm{M}$ & \\
\hline WPMS_20 & Smulders i sur. 2001 & Сy5 & $224-254$ & 6 & 3 & $2 \mu \mathrm{M}$ & \\
\hline WPMS_05 & van der Schoot i sur. 2000 & BMN-6 & 185-305 & 13 & 3 & $2 \mu \mathrm{M}$ & \\
\hline ORPM_23 & Tuskan i sur. 2004 & DY-751 & 171-193 & 11 & 3 & $2 \mu \mathrm{M}$ & \\
\hline PMGC_456 & IPGC & Cy5 & $79-86$ & 3 & 3 & $5 \mu \mathrm{M}$ & \\
\hline
\end{tabular}

(* specifični alel za P. deltoides). IPGC - Populus Molecular Genetics Cooperative (htto://www.orni.gov/sci/ipgc/ssr_resource.htm):

International Populus Genome Consortium 
Tablica 3. Broj registriranih alela prema populacijama

Table 3. Number of registered alleles according to investigated populations

\begin{tabular}{|c|c|c|c|c|c|c|c|c|c|c|c|}
\hline \multirow{2}{*}{$\begin{array}{l}\text { Genski lokus } \\
\text { Gene locus }\end{array}$} & \multicolumn{11}{|c|}{ Populacije (Dio riječnog slijeva)- Populations } \\
\hline & $\begin{array}{l}\text { Neretva } \\
\text { gornji tok }\end{array}$ & $\begin{array}{l}\text { Neretva } \\
\text { donji tok }\end{array}$ & $\begin{array}{c}\text { Vrbas } \\
\text { gornji tok }\end{array}$ & $\begin{array}{c}\text { Vrbas } \\
\text { srednji tok }\end{array}$ & $\begin{array}{c}\text { Vrbas } \\
\text { donji tok }\end{array}$ & $\begin{array}{l}\text { Bosna } \\
\text { gornji tok }\end{array}$ & $\begin{array}{c}\text { Bosna } \\
\text { srednji tok }\end{array}$ & $\begin{array}{c}\text { Bosna } \\
\text { donji tok }\end{array}$ & Spreča & $\begin{array}{c}\text { Drinja } \\
\text { gornji tok }\end{array}$ & $\begin{array}{c}\text { Drina } \\
\text { donji tok }\end{array}$ \\
\hline PMGC_14 & 5 & 2 & 2 & 6 & 6 & 8 & 5 & 7 & 7 & 6 & 6 \\
\hline WPMS_09 & 4 & 3 & 4 & 8 & 9 & 11 & 8 & 8 & 8 & 7 & 7 \\
\hline WPMS_18 & 5 & 4 & 3 & 5 & 8 & 7 & 5 & 6 & 7 & 5 & 6 \\
\hline WPMS_12 & 3 & 4 & 2 & 5 & 6 & 7 & 8 & 6 & 7 & 5 & 5 \\
\hline WPMS_14 & 6 & 2 & 3 & 5 & 6 & 7 & 8 & 8 & 6 & 5 & 7 \\
\hline PMGC_21636 & 6 & 3 & 4 & 9 & 9 & 15 & 11 & 11 & 6 & 5 & 9 \\
\hline PMGC_456 & 1 & 1 & 2 & 2 & 1 & 2 & 2 & 3 & 2 & 2 & 2 \\
\hline ORPM_23 & 8 & 4 & 3 & 6 & 6 & 9 & 5 & 7 & 5 & 7 & 6 \\
\hline WPMS_20 & 5 & 5 & 3 & 5 & 5 & 6 & 5 & 6 & 5 & 5 & 5 \\
\hline WPMS_05 & 8 & 6 & 3 & 8 & 6 & 9 & 5 & 6 & 5 & 10 & 6 \\
\hline Ukupno alela & 51 & 34 & 29 & 59 & 62 & 81 & 62 & 68 & 58 & 57 & 59 \\
\hline
\end{tabular}

likost, čak i u malim, izoliranim populacijama koje su obuhvaćene ovim istraživanjem, te uz ograničen broj stabala.

Kada integralno analiziramo rječne slivove, $\mathrm{u}$ ovom istraživanju je registrirana 100\% polimorfnost (p\%) kod svih analiziranih lokusa izuzev populacije Neretva, gdje je registrirano $90 \%$ polimorfnih genskih lokusa. Također je registriran udio nespecifičnih alela koji su nađeni kod 17 individua iz svih istraživanih populacija. Zbog tog malog broja specifičnih alela, nismo bili u mogućnosti da ovo istraživanje iskoristimo za određivanje migracija poslije zadnje glacijacije. Inače populacija donji tok Neretve i gornji tok Vrbasa pokazuje najmanje vrijednosti broja alela za šest ispitivanih genskih lokusa (Tablica 3.).

Interesantna je usporedba broja analiziranih individua $\mathrm{i}$ utvrđenih genotipova. Kako je jako mali broj stabala zbog ograničenog broja starih stabala, tako u populaciji gornjeg toka Vrbasa imamo kod sedam stabala samo tri genotipa, dok u populaciji gornji tok Bosne kod 20 stabala imamo 19 genotipova. Tako je kod detekcije od 10 genskih lokusa registrirano za gornji tok Vrbasa samo 29 alela, dok je u populaciji gornji tok Bosne registriran 81 alel (Tablica 3.).

Analizom alelne raznolikosti možemo primijetiti da populacija gornjeg toka rijeke Bosne pokazuje najveću vrijednost, dok populacijeiz gornjeg toka Vrbasa i donjeg toka Neretve imaju najmanju alelnu raznolikost (Tablica 4.). Inače alelna raznolikost se kretala od 1,000 za PMGC_456 kod populacija Neretva i donji tok Vrbasa, do 11,765 za genski lokus PMGC_2163 u populaciji gornjeg toka Bosne. Za populaciju donje Neretve je interesantno da su za osam genskih lokusa dobivene najmanje vrijednosti alelne raznolikosti (Tablica 4.). Kada analizirano populacijsku raznolikost tada primjećujemo da je donji tok Neretve s najmanjom vrijednošću, a gornji tok Bosne s najvećom.

Vrlo važno mjerilo genetičke raznolikosti u populaciji je heterozigotnost, koja zapravo označava broj heterozigota u istraživanoj populaciji. Stvarne heterozigotnosti su skoro u

Tablica 4. Alelna raznolikost - efektivni broj alela

Table 4. Allelic diversity - effective number of alleles

\begin{tabular}{|c|c|c|c|c|c|c|c|c|c|c|c|}
\hline \multirow{2}{*}{$\begin{array}{l}\text { Genski lokus } \\
\text { (Genski lokus) }\end{array}$} & \multicolumn{11}{|c|}{ Populacije (Dio riječnog slijeva) - Population } \\
\hline & $\begin{array}{l}\text { Neretva } \\
\text { gornji tok }\end{array}$ & $\begin{array}{l}\text { Neretva } \\
\text { donji tok }\end{array}$ & $\begin{array}{c}\text { Vrbas } \\
\text { gornji tok }\end{array}$ & $\begin{array}{c}\text { Vrbas } \\
\text { srednji tok }\end{array}$ & $\begin{array}{c}\text { Vrbas } \\
\text { donji tok }\end{array}$ & $\begin{array}{c}\text { Bosna } \\
\text { gornji tok }\end{array}$ & $\begin{array}{c}\text { Bosna } \\
\text { srednji tok }\end{array}$ & $\begin{array}{l}\text { Bosna } \\
\text { donji tok }\end{array}$ & Spreča & $\begin{array}{c}\text { Drinja } \\
\text { gornji tok }\end{array}$ & $\begin{array}{l}\text { Drina } \\
\text { donji tok }\end{array}$ \\
\hline PMGC_14 & 1,841 & 1,074 & 2,000 & 3,571 & 3,488 & 3,756 & 4,215 & 2,970 & 3,879 & 2,947 & 4,321 \\
\hline WPMS_09 & 2,348 & 1,931 & 2,970 & 5,882 & 4,945 & 6,299 & 4,308 & 5,600 & 5,565 & 5,158 & 5,042 \\
\hline WPMS_18 & 3,115 & 3,240 & 2,513 & 2,985 & 6,081 & 4,624 & 4,455 & 3,240 & 5,818 & 4,667 & 3,841 \\
\hline WPMS_12 & 2,455 & 2,306 & 1,849 & 2,469 & 3,571 & 3,556 & 4,558 & 3,187 & 4,267 & 3,294 & 3,507 \\
\hline WPMS_14 & 2,842 & 1,237 & 2,513 & 4,000 & 4,167 & 4,762 & 6,031 & 5,444 & 4,267 & 4,041 & 4,172 \\
\hline PMGC_2163 & 2,945 & 1,537 & 2,970 & 7,143 & 4,787 & 11,765 & 7,127 & 7,686 & 4,571 & 3,187 & 6,368 \\
\hline PMGC_456 & 1,000 & 1,000 & 1,324 & 1,342 & 1,000 & 1,280 & 1,153 & 1,446 & 1,280 & 1,074 & 1,095 \\
\hline ORPM_23 & 3,951 & 2,074 & 1,556 & 4,000 & 4,369 & 6,061 & 2,347 & 5,026 & 2,723 & 4,780 & 5,149 \\
\hline WPMS_20 & 4,765 & 3,039 & 2,513 & 4,444 & 3,846 & 4,762 & 3,439 & 3,769 & 3,657 & 3,439 & 4,033 \\
\hline WPMS_05 & 4,909 & 2,800 & 2,178 & 5,128 & 3,947 & 4,734 & 4,612 & 4,667 & 3,556 & 5,227 & 4,172 \\
\hline Gene pool & 2,466 & 1,719 & 2,099 & 3,339 & 3,201 & 3,868 & 3,311 & 3,544 & 3,333 & 3,091 & 3,370 \\
\hline
\end{tabular}


Tablica 5. Genetska varijabilnost: heterozigotnost i fiksacijski indeks Table 5. Genetic variability: heterozygosity and fixation index

\begin{tabular}{lccr} 
Populacija & \multicolumn{1}{c}{$\begin{array}{c}\text { Heterozigotnost } \\
\text { Population }\end{array}$} & $\begin{array}{r}\text { Fiksacijski } \\
\text { indeks }\left(F_{i}\right) \\
\text { Fixation } \\
\text { index }\end{array}$ \\
\cline { 2 - 3 } Neretva gornji tok & 0,678 & 0,594 & $-0,164$ \\
observed) & $\begin{array}{c}\text { He (očekivana/ } \\
\text { expected) }\end{array}$ & 0,062 \\
Neretva donji tok & 0,379 & 0,418 & $-0,524$ \\
Vrbas gornji tok & 0,814 & 0,523 & $-0,041$ \\
Vrbas srednji tok & 0,730 & 0,701 & 0,054 \\
Vrbas donji tok & 0,653 & 0,688 & 0,051 \\
Bosna gornji tok & 0,720 & 0,742 & $-0,038$ \\
Bosna srednji tok & 0,729 & 0,698 & 0,034 \\
Bosna donji tok & 0,707 & 0,718 & 0,016 \\
Spreča & 0,738 & 0,700 & $-0,095$ \\
Drinja gornji tok & 0,743 & 0,677 & 0,052 \\
Drina donji tok & 0,655 & 0,703 &
\end{tabular}

svim slučajevima veće od teorijskih (Tablica 5.), ili su razlike minimalne što ukazuje na odsustvo imbridinga ili je u pitanju mala vrijednost. Ovdje se treba osvrnuti i na populaciju Gornjeg toka Vrbasa kod kojeg imamo samo tri genotipa, što je ostavilo traga i na heterozigotnosti ove populacije.

Razlike između stvarne i teorijske heterozigotnosti pokazuju odstupanje stvarnog stanja od uravnoteženog stanja populacije, a što je bilo i za očekivati s obzirom na veličinu i strukturu istraživanih populacija. Tako je dobivena najveća razlika kod populacije donji tok Neretve, te je vrijednost fiksacijskog indeksa $\mathrm{F}_{\mathrm{i}}=0,062$.

Fiksacijski indeks u pet istraživanih populacija pokazuje negativne veličine (Tablica 5.) ili male pozitivne vrijednosti, osim donjeg toka Neretve s relativno većom vrijednošću, ali bez značajnijeg imbridinga u populaciji. Možemo utvr- diti da su sve populacije u skoro uravnoteženom stanju. Ipak ovdje se moramo i ograditi od dobivenih rezultata fiksacijskog indeks s obzirom na veličinu istraživanih populacija, kod kojih je bio jako mali broj starih stabala.

Ukupna diferenciranost istraživanih populacija iznosila je $\mathrm{dj}=0,3738$, što je visoka vrijednost za jednu pionirsku vrstu. U bosanskohercegovačkim populacijama crnih topola prisutna je relativno visoka unutarpopulacijska diferenciranost i kretala se od dj $=0,2917$ za donji tok Bosne do $d j=0,5545$ za donji tok rijeke Neretve.

Diferenciranost prema genskim lokusima (biljezima) kretala se od dj=0,1090 za genski lokus PMGC_456 kod donjeg toka Bosne, gdje se zadržao veći broj starih autohtonih stabala topola, do dj=0,8995 kod donjeg toka Neretve za genski lokus WPMS_14.

Dobiveni rezultati između istraživanih populacija u Tablici 6. mogu se protumačiti malim zemljopisnim udaljenostima između analiziranih populacija, teprotoka gena između njih. Populacije Neretva i gornji tok Vrbasa pokazuju specifičnost. U populaciji gornji Vrbas imamo samo tri genotipa, iako su stabla sakupljena sa jednog šireg područja. Populacija donjeg toka Neretve (Čapljina) izolirana je od ostalih, a pripada Jadranskom slivu uz nisku raznolikost i heterozigotnost, te visoku vrijednost diferenciranja u njoj, što ukazuje da nema protoka gena iz drugih populacija. Također provedena analiza uz pomoć programa STRUCTURE 2.2 $s$ klasterima $\mathrm{K}=3$, ilustrativno pokazuje značajnu diferenciranost populacije donja Neretva (Slika 2).

Kada se primjeni ista metoda s klasterom $\mathrm{K}=4$ dobijemo grupiranje populacija Vrbasa, Drine i Bosne, te Spreče i pokazuju značajnu raznolikost, dok populacija gornji tok Neretve (Konjic) pokazuje sličnost s populacijama rijeke Bosne (Slika 3).

Tablica 6. Genetska diferenciranost (dj) prema Gregoriusu (1987)

Table 6. Genetic differentiation (dj) according to Gregorius (1987)

\begin{tabular}{|c|c|c|c|c|c|c|c|c|c|c|c|c|}
\hline \multirow[b]{2}{*}{ Genski lokus } & \multicolumn{12}{|c|}{ Populacije (Dio riječnog slijeva) - Population } \\
\hline & 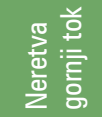 & 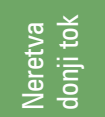 & 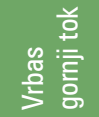 & 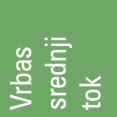 & 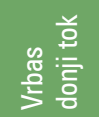 & 总: & 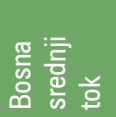 & 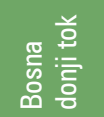 & 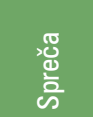 & 爱总 & 兽 & 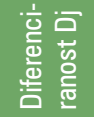 \\
\hline PMGC_14 & 0,4178 & 0,5853 & 0,3763 & 0,4621 & 0,4632 & 0,1505 & 0,2888 & 0,2400 & 0,3009 & 0,3015 & 0,3696 & 0,3596 \\
\hline WPMS_09 & 0,6006 & 0,6776 & 0,7033 & 0,4636 & 0,4560 & 0,3971 & 0,4653 & 0,3862 & 0,3890 & 0,4457 & 0,5535 & 0,5034 \\
\hline WPMS_18 & 0,5450 & 0,5445 & 0,5098 & 0,4472 & 0,2573 & 0,2885 & 0,3400 & 0,3592 & 0,1526 & 0,3240 & 0,4261 & 0,3813 \\
\hline WPMS_12 & 0,4955 & 0,6568 & 0,6684 & 0,6183 & 0,4717 & 0,2431 & 0,2867 & 0,3299 & 0,2271 & 0,2564 & 0,3926 & 0,4224 \\
\hline WPMS_14 & 0,5777 & 0,8995 & 0,4958 & 0,3756 & 0,4291 & 0,2625 & 0,4422 & 0,2663 & 0,2551 & 0,3918 & 0,3801 & 0,4342 \\
\hline PMGC_2163 & 0,6910 & 0,7045 & 0,7880 & 0,5245 & 0,4173 & 0,3368 & 0,3217 & 0,3965 & 0,5903 & 0,6668 & 0,6081 & 0,5496 \\
\hline PMGC_456 & 0,0874 & 0,0874 & 0,0769 & 0,0847 & 0,0874 & 0,0572 & 0,0088 & 0,1090 & 0,0572 & 0,0481 & 0,0374 & 0,0674 \\
\hline ORPM_23 & 0,2973 & 0,5167 & 0,6749 & 0,3385 & 0,4244 & 0,2281 & 0,4813 & 0,3414 & 0,5483 & 0,4454 & 0,2869 & 0,4166 \\
\hline WPMS_20 & 0,1197 & 0,3237 & 0,5504 & 0,1526 & 0,2129 & 0,1998 & 0,3563 & 0,2741 & 0,2389 & 0,2756 & 0,1796 & 0,2621 \\
\hline WPMS_05 & 0,3068 & 0,5486 & 0,6550 & 0,2980 & 0,3714 & 0,1982 & 0,3141 & 0,2145 & 0,3841 & 0,1683 & 0,2969 & 0,3415 \\
\hline Gene pool & 0,4139 & 0,5545 & 0,5499 & 0,3765 & 0,3591 & 0,2362 & 0,3305 & 0,2917 & 0,3144 & 0,3324 & 0,3531 & \\
\hline
\end{tabular}




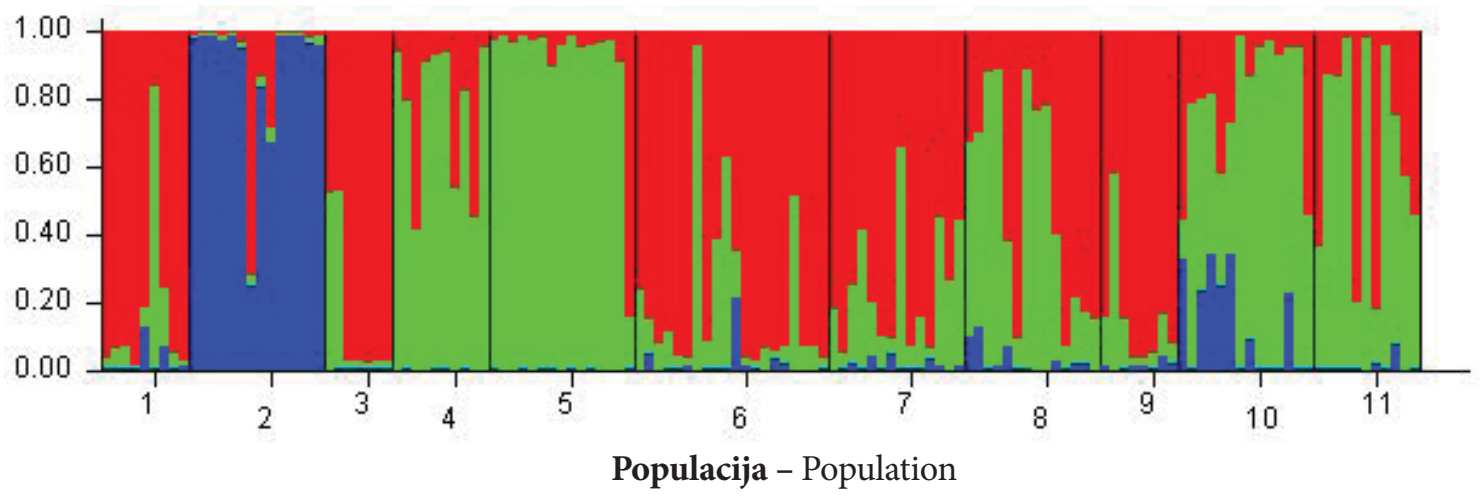

Slika 2 Zemljopisna reprezentativnost klastera s K= 3 skupine za svih 136 individua iz 11 populacija

Figure 2 Graphical representation of cluster membership in $\mathrm{K}=3$ groups for all 136 idividuals from 11 populations

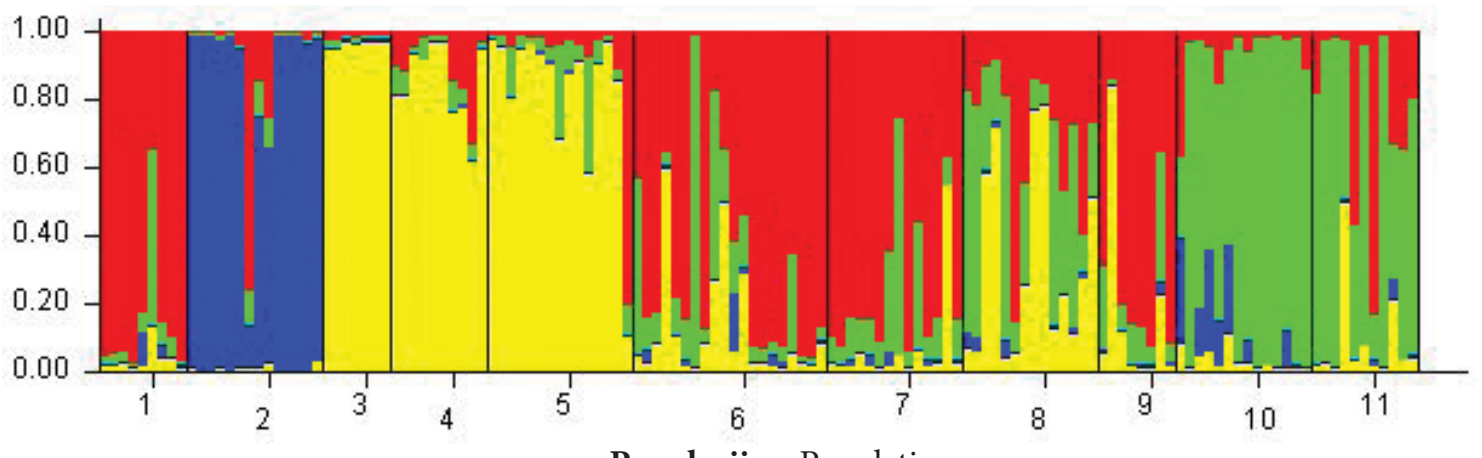

Populacija - Population

Slika 3 Zemljopisna reprezentativnost klastera s $K=4$ skupine za svih 136 individua iz 11 populacija

Figure 3 Graphical representation of cluster membership in $K=4$ groups for all 136 idividuals from 11 populations

Tablica 7. Postotak varijabilnosti na temelju prve tri osi

Table 7. Percentage of variability based on the first three axes

\begin{tabular}{lccc} 
& \multicolumn{3}{c}{ Osi/Axes } \\
\cline { 2 - 4 } & 1 & 2 & 3 \\
\hline prema osi & 28,67 & 21,00 & 14,58 \\
Kumulanta u \% & 28,67 & 49,67 & 64,25
\end{tabular}

Nakon što iz statističke analize isključimo ekstremne vrijednosti, rezultati dobiveni putem principal komponent analize programom GeneAlEx, temeljenim na Nei-ovim
(1972) genetskim odstojanjimapokazuju diferencijaciju (Tablica 7., Slika 4).

Iz Slike 4 je vidljivo grupiranje u središnjem dijelu populacija rijeke Bosne i Spreče, te još dvije podskupine, dviju populacija rijeke Vrbas i Drine, sa sličnim udaljenostima spram populacija rijeke Bosne, a što je vidljivo i iz Tablice 8.

Kada analiziramo genotipska odstojanja u Tablici 8. možemo primijetit da najveća odstupanja pokazuju populacije Neretve i gornji tok Vrbasa, a što je potvrđeno prethodnim analizama i bilo je za očekivati.

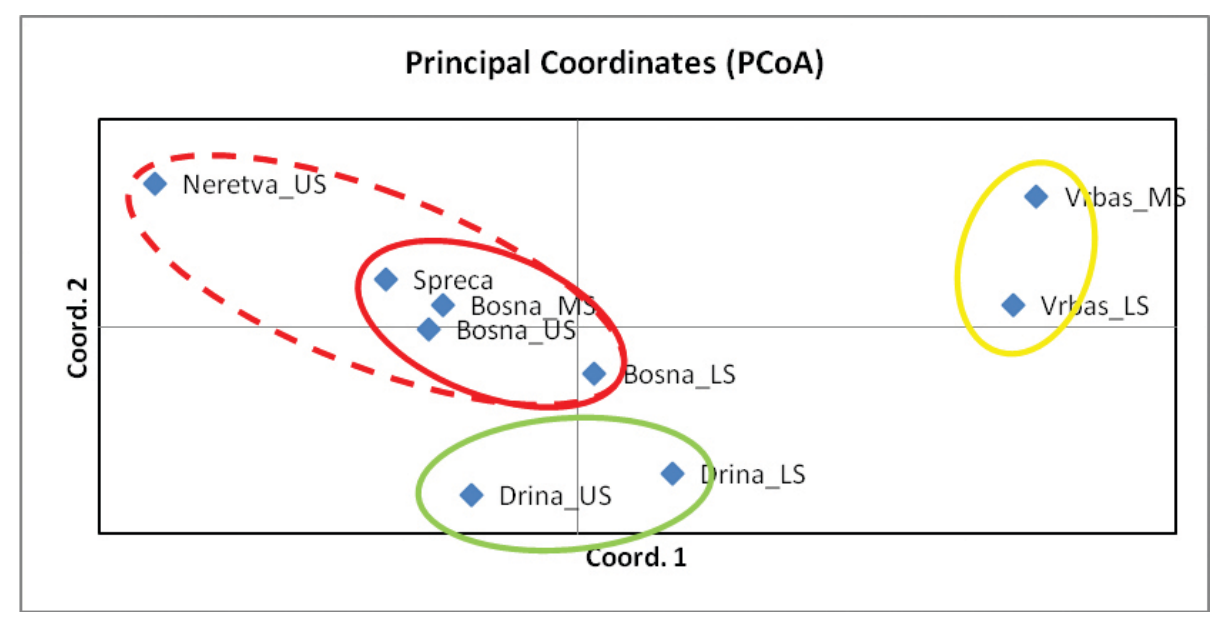


Tablica 8. Genotipska odstojanja prema Gregoriusu (1974)

Table 8. Genotypic distance according to Gregorius (1974)

\begin{tabular}{|c|c|c|c|c|c|c|c|c|c|c|}
\hline Populacija & $\begin{array}{l}\text { Neretva } \\
\text { donji tok }\end{array}$ & $\begin{array}{c}\text { Vrbas } \\
\text { gornji tok }\end{array}$ & $\begin{array}{c}\text { Vrbas } \\
\text { srednii tok }\end{array}$ & $\begin{array}{c}\text { Vrbas } \\
\text { donji tok }\end{array}$ & $\begin{array}{l}\text { Bosna } \\
\text { gornji tok }\end{array}$ & $\begin{array}{c}\text { Bosna } \\
\text { srednji tok }\end{array}$ & $\begin{array}{c}\text { Bosna } \\
\text { donji tok }\end{array}$ & Spreča & $\begin{array}{c}\text { Drinja } \\
\text { gornji tok }\end{array}$ & $\begin{array}{c}\text { Drina } \\
\text { donji tok }\end{array}$ \\
\hline Neretva gornji tok & 0,533 & 0,610 & 0,514 & 0,508 & 0,370 & 0,433 & 0,469 & 0,433 & 0,500 & 0,489 \\
\hline Neretva donji tok & & 0,689 & 0,681 & 0,640 & 0,572 & 0,586 & 0,575 & 0,553 & 0,507 & 0,601 \\
\hline Vrbas gornji tok & & & 0,554 & 0,580 & 0,503 & 0,632 & 0,518 & 0,549 & 0,579 & 0,601 \\
\hline Vrbas srednji tok & & & & 0,350 & 0,400 & 0,455 & 0,404 & 0,429 & 0,474 & 0,450 \\
\hline Vrbas donji tok & & & & & 0,415 & 0,443 & 0,34 & 0,449 & 0,455 & 0,378 \\
\hline Bosna gornji tok & & & & & & 0,375 & 0,342 & 0,321 & 0,366 & 0,375 \\
\hline Bosna srednji tok & & & & & & & 0,389 & 0,342 & 0,411 & 0,397 \\
\hline Bosna donji tok & & & & & & & & 0,360 & 0,361 & 0,394 \\
\hline Spreča & & & & & & & & & 0,426 & 0,426 \\
\hline Drinja gornji tok & & & & & & & & & & 0,346 \\
\hline
\end{tabular}

\section{RASPRAVA}

\section{DISCUSSION}

Dobiveni rezultati pokazuju da su, uz pomoću korištenih mikrosatelitskih biljega, razlike između populacija ili unutar populacija crnih topola vidljive i jasne. Mogući uzroci tih razlika, osim prirodne selekcije,u jakom su antropogenom djelovanju, kao i razvojnim čimbenicima ili procesima prilagođavanja na izmijenjene ekološke uvjete u posljednjih 150 godina, kako je utvrđeno i kod hrastova (Ballian i sur. 2010).

Samo područje Bosne i Hercegovine vrlo je specifično kada su posrijedi uvjeti okoliša, jer na vrlo malom prostoru postoji velika šarolikost klimatskih, edafskih, orografskih i drugih čimbenika, a koji izravno utječu na diferencijaciju različitih ekotipova, a time i do genetičke diferenciranosti, što se na temelju istraživanja morfoloških svojstava utvrdilo kod crnih topola (Kajba i sur. 2004, 2015). Stoga se smatra da vrste šumskog drveća iz Bosne i Hercegovine pokazuju veliku varijabilnost, u usporedbi $s$ istim vrstama iz središnje, zapadne i istočne Europe, a što je potvrđeno na molekularnoj razini (Ballian i sur. 2008, 2010).

Kakav je utjecaj ekoloških čimbenika, odnosno genetičko prilagođavanje crnih topola na određeno stanište na morfološkoj razini kod populacije Neretve prikazali su Kajba i sur. (2004, 2015),Ballian i sur. (2006), te na fiziološkoj razini De Woody (2011), a rezultati ovih istraživanja to potvrđuju na molekularno genetskoj razini. Također dobiveni rezultati, s obzirom na registrirane specifične alele, ipak ukazuju na relativnu blizinu glacijalnog pribježišta na Balkanskom poluotoku o čemu izvještava Cottrell i sur. (2005), koje je možda utjecalo na današnju genetičku varijabilnost populacija i njihovo diferenciranje.

Iz dobivenih rezultata u ovom istraživanju možemo izvesti zaključak da postoje razlike među populacijama iz različitih ekoloških niša (Stefanović i sur. 1983), u našem slučaju riječnih slivova, odnosno da je vjerojatan razlog tomu i jaki antropogeni utjecaj kroz povijest, ili su ipak razlike u klimi između staništa najznačajnije utjecale na genetičku diferencijaciju između populacija o čemu pišu neki od autora (Kajba i sur. 2004; Ballian i sur. 2006; De Woody 2011). Ako morfološka diferencijacija strogo prati razlike u okolišu, tada se trenutna diferenciranost uspoređuje na temelju morfotipova i razlika u okolišu, a kao rezultat dobijemo dobre smjernice za radove na očuvanju (Sork i sur. 2010; Kremer i sur. 2012). Međutim, ako morfološka diferencijacija odražava kombinaciju prilagodljivih i neadaptivnih procesa tada je predviđanje odgovora vrste na klimatske promjena prilično komplicirano, te genetska varijabilnost ne smije odgovarati adaptivnom fenotipu za određenu okolinu (De Woody i sur. 2015). Stoga se dobivene veličine genetskih parametara moraju promatrati uvjetno, jer možda nisu samo posljedica prirodnih procesa i genetičke diferenciranosti kod kontinentalnih bosanskih populacija. Situacija s populacijom Neretva je potpuno drukčija, jer je uz sve i pod jakim izravnim utjecajem toplog i suhog submediteranskog klimata (Kajba i sur. 2004; De Woody 2011), a koji duboko prodire dolinom Neretve u unutrašnjost Bosne i Hercegovine (Stefanović i sur. 1983).

Također i u Europi postoji dobra genetska varijabilnost crnih topola uz nisku stopu diferenciranosti, jer je prisutan protok gena između populacija, a što su na razini izoenzimskih istraživanja potvrdili Legionet i Lefevre (1996), na molekularno genetskoj razini Winfield i sur. (1998), Cottreli i sur. $(1997,2002)$, a na haplotipskoj razini Cottreli i sur. (2005). Za razliku od njih van Dam i sur. (2002) su uz primjenu morfoloških, izoenzimskih i DNK biljega dobili zadovoljavajuću diferenciranost između i unutar nekoliko riječnih sustava u Europi. Do sličnih rezultata došli su Božić i sur. (2010) za riječne sustave u Austriji, Sloveniji i Hrvatskoj. Primjenom više početnica, od kojih su neke bile iste kao u našem istraživanju, De Woody i sur. (2015) dobili su veću varijabilnost i heterozigotnost. Za razliku od našeg 
istraživanja isti autor je dobio više negativnih vrijednosti fiksacijskog indeksa, te bi se za pojavu pozitivnih vrijednosti morali pozvati na jaki antropogeni utjecaj.

Poznavanje genetičke varijabilnosti crnih topola može osigurati da se u Bosni i Hercegovini donesu planovi za obnovu topolovih šuma, njenu reintrodukciju, kao i očuvanje genetičke raznolikosti metodom in situ, s obzirom na potencijal od 40000 ha koji su za sada neiskorišteni. U radovima na obnovi treba dati prednost prirodnom pomlađivanju, ili unošenju autohtonog klonskoga reprodukcijskog materijala iz klonskog arhiva u Žepču (Ballian 2009). Prilikom provođenja redovne provjere uspješnosti očuvanja genetičke raznolikosti kod mladih populacija, trebali bi se služiti analizom mikrosatelitskih biljegakoja se pokazala veoma uspješnom u ovom istraživanju.

Veza ispitivanih mikrosatelitnih regija s određenim sposobnostima adaptacije crnih topola u ovom istraživanju nije registrirana na zadovoljavajućoj razini, ali rezultati koji su dobiveni za populaciju Neretva ukazuju na to, kao i s obzirom na neka druga istraživanja s kojima možemo napraviti usporedbe (Kajba i sur. 2004, 2015; Ballian i sur. 2006; De Woody 2011; De Woody i sur. 2015). Isto tako i primarni populacijski genetički parametri mogu dati važne dokaze o adaptivnosti jedinke ili populacije, a to se ponajprije ogleda u podacima o genetskoj raznolikosti, broju alela, efektivnom broju alela, alelnoj raznolikosti, genetskoj multilokusnoj raznolikosti, stupnju heterozigotnosti, a što je također dobiveno u ovom istraživanju. Njihovim promatranjima i sintezom rezultata mogu se donijeti odgovarajuće preporuke radi očuvanja genetske biološke raznolikosti populacija, odnosno uspješne obnove populacija.

Kad je u pitanju veličina genetske varijabilnosti, mnogi istraživači postavili su hipotezu da mala varijabilnost uzrokuje propadanje populacije i vrste (Larsen 1986), te stoga s obzirom na dobivene veličine heterozigotnosti istraživane populacije trebale bi iskazati visok stupanj otpornosti, kao i one u Europi s kojima je radila De Woody i sur. (2015). Ta tvrdnja se može temeljiti na istraživanjima u zapadnoj Europi, gdje crna topola ima relativno manju diferenciranost (Legionet i Lefèvre 1996; Arens i sur. 1998; Winfield i sur. 1998; Pospišková i Bartáková 2004; Božič i sur. 2010), u odnosu na rezultate iz ovog istraživanja, kao i iz istraživanja De Woody i sur. (2015), gdje su populacije pokazale visoku varijabilnosti i heterozigotnost. Osim toga, na heterozigotnost populacija uvelike utječe i tip gospodarenja u određenim područjima, tijekom dužeg vremena, što je usmjeravalo raznolikost u pozitivnom ili negativnom smjeu, a treba znati da su bosanskohercegovačke populacije crnih topola prilično devastirane, s jako narušenom strukturom, a što sigurno ima utjecaj na njenu genetsku strukturu.

Na temelju dobivenih rezultata u istraživanim populacijama situacija je vrlo složena. Imamo male populacije s dobrom heterozigotnošću i koje karakterizira pojava polimorfizma nesrazmjerna prema njihovoj veličini. Inače za vrste s disjunktnim rasprostiranjem, kao što je crna topola u Bosni i Hercegovini, svojstveno je da pokazuju veliku međupopulacijsku varijabilnost i umjerenu unutarpopulacijsku varijabilnost na molekularnoj razini.

U populacijama s pojavom rijetkih alela prilikom njihove obnove posebno bi trebalo voditi računa o strukturi mlade sastojine, kako bi se omogućilo prenošenje rijetkih alela u sledeću generaciju, po mogućnosti prirodnom obnovom, ali ako se to pokaže nedovoljnim, pristupiti i umjetnoj obnovi.

\section{ZAKLJUČCI}

\section{CONCLUSIONS}

Provedenom molekularnom analizom genetske strukture šest populacija (riječnih slivova) crnih topola, uz uporabu deset mikrosatelitskih genskih lokusa dobili smo značajne genetičke razlike.

Registriran je velik polimorfizam, a u populaciji donji tok Neretve i gornji tok Vrbasa registriran je najmanj broj alela (34 i 29), dok je u populaciji gornji tok Bosne registriran ukupno 81alel.

Alelna raznolikost se prema biljezima kretala od 1 za genski lokus PMGC_456 u populacijama Neretva i donji tok Vrbasa, do 11,333 za genski lokus PMGC_2163 u populaciji gornjeg toka Bosne. Kod populacije Neretva prisutno je pet genskih lokusa s najmanjim vrijednostima.

Stvarne heterozigotnosti su skoro u svim slučajevima manje od teorijskih, koje se ponašaju sukladno stvarnim heterozigonostima.

Fiksacijski indeks u svim istraživanim populacijama pokazuje negativne ili vrlo male pozitivne veličine, ali s relativno malim vrijednostima, osim u slučaju populacije Neretva kod koje imamo odstupanje, a prosječni koeficijent inbridinga iznosio je $\mathrm{F}=0,062$.

$\mathrm{U}$ istraživanim populacijama prisutna je relativno visoka unutarpopulacijska diferenciranost, koja se kretala od dj = 0,2917 kod donjeg toka rijeke Bosne, do dj= 0,5545 kod donjeg toka Neretve, a slijedi je populacija gornjeg toka Vrbasa. Dobiveni rezultati mogu se protumačiti malim zemljopisnim udaljenostima između analiziranih populacija, s tim da je populacija Neretva izolirana i pripada Jadranskom slijevu.

Najveće genetske udaljenosti prema Gregoriusu pokazuju populacije s Neretve i gornjeg toka Vrbasa.

Metode uporabe molekularnih biljega, za određenje genetske strukture crnih topola, su dale dobru genetičku sliku o istraživanim populacijama, a dobiveni rezultati osiguravaju preporukei potrebne mjere za očuvanje genetskih izvora ove vrste u Bosni i Hercegovini. 


\section{LITERATURA}

\section{REFERENCES}

- Arens P., H. Coops, J. Jansen, B. Vosman, 1998: Molecular genetic analysis of black poplar (Populus nigra L.) along Dutch rivers. Molecular Ecology 7: 11-18.

- Back-Mannagetta G. 1906: Flora Bosne i Hercegovine i Novopazarskog sandžaka, 2(1) dio. Glas. Zem. Muz., 18. Sarajevo.

- Ballian D. 2004: The status of Black and White Poplar (Populus nigra L., Populus alba L.) in Bosnia and Herzegovina, In Populus nigra Network. Report of the $8^{\text {th }}$ Populus nigra Network Meeting, Frankfurt (Oder)/Treppeln. IPGRI, Italy, str. 17-20. Rome.

- Ballian D., T. Mikić, 1999: Kako nestaje autohtona Europska crna topola (Populus nigra L.) i kako je sačuvati, Biološki list, god. XLVI, str. 9-12. Sarajevo.

- Ballian D., D. Kajba, M. Idžojtić, 2006: Morphological diversity of black hairy poplar (Populus nigra subsp. caudina) in Bosnia and Herzegovina. The Fourth International Poplar Symposium „Meeting the Needs of a Growing World through Poplar and Willow Science: Combining Traditional and Novel Approaches in the Genomic Era" Nanjing, China June 5-9, 2006. Book of abstract str. 74. Nanjing.

- Ballian D., F. Mekić, 2008a: The Clone Archive of Black Poplar (Populus nigra L.) In Žepče, Bosnia and Herzegovina. IPC 2008 - CHINA, 23rd SESSION, INTERNATIONAL POPLAR COMMISSION, BEIJING - CHINA 27 - 30 October 2008. Book of abstracts: str. 12. Beijing.

- Ballian D., F. Mekić, 2008b: Klonski arhiv Bosanskohercegovačkih populacija crne topole (Populus nigra L.) u Žepču - podizanje i uporaba klonskog materijala. Naše šume, 12/13:16-24.Beijing.

- Ballian D., I. Monteleone, D. Ferrazzini, D. Kajba, P. Belletti, 2008: Genetic characterization of common ash (Fraxinus excelsior L.) population in Bosnia and Herzegovina. Periodicum Biologorum, Vol. 110, 4: 323-328. Zagreb.

- Ballian D., P. Belletti, D. Ferrazzini, F. Bogunić, D. Kajba, 2010: Genetic variability of pedunculate oak (Quercus robur L.) in Bosnia and Herzegovina. Periodicum biologorum, 112 (3): 353 362. Zagreb.

- Ballian D., D. Kajba, 2011: Oplemenjivanje šumskog drveća i očuvanje njegove genetske raznolikosti. Univerzitetski Sveučilišni udžbenik. Str. 1-299. Sarajevo-Zagreb.

- Bisoffi S., G. Gemignani, M.A. Gras, S. May, G. Mughini, 1987: Establishment of Populus nigra genetic reserve in Italy. Genet. Agr. 41: 105-114.

- Božić G., B. Heinze, D. Kajba, V. Krystufek, A. Vanden Broeck, 2010: Genetic diversity in Populus nigra L. populations along rivers in Eastern Austria, Slovenia and Croatia as revealed by microsatellite markers. In: Spano P, Cherubini L (ed) Fifth International Poplar Symposium, Poplars and Willows: from research models to multipurpose trees for a bio-based society, Orvieto, Italy, 20-25 September 2010, str. 22. Orvieto.

- Cottrell J.E., G.I. Forrest, I.M.S. White, 1997: The use of RAPD analysis to study diversity in British black poplar (Populus nigra L. subsp. betulifolia (Pursch) W. Wettst. (Salicaceae)) in Great Britain. Watsonia, 21: 305-312.

- Cottrell J.E., H.E. Tabbener, G.I. Forrest, 2002: Distribution of variation in British black poplar: role for human management. In: Van Dam B.C., Bordács S. (Ed.), Genetic Diversity in River Populations of European Black Poplar-implications for Ripar- ian Eco-system Management. Proceedings of an International Symposium, Szekza'rd, Hungary, May 2001, str.73-84.

- Cottrell J.E., V. Krystufek, H.E. Tabbener, A.D. Milner, T. Connolly, L. Sing, S. Fluch, K. Burg, F. Lefévre, R. Achard, S. Bordács, K. Gebhardt, B. Vornam, M.J.M. Smulders, A.H. Vanden Broeck, J. Van Slycken, V. Storme, W. Boerjan, S. Castiglione, T. Fossati, N. Alba, D. Agundez, C. Maestro, E. Notivol, J. Bovenschen, B.C. Van Dam, 2005: Postglacial migration of Populus nigra L.: lessons learnt from chloroplast DNA. Forest Ecology and Management 206: 71-90.

- Čortan D., B. Tubić, M. Šijačić-Nikolić, D. Borota, 2015: Variability of black poplar (Populus nigra L.) leaf morphology in Vojvodina, Serbia. Šumarski list, 5-6: 245-252.

- Cremer E., M. Konnert, 2010: Genetische Untersuchungen an Schwarzpappeln aus Bayern. In: LWF Wissen, Heft 64, 46-51.

- Degen B. 2008. Computer Program GDA_NT - Genetic Data Analysis \& Numerical Tests. Version 2, May 2008.

- De Woody J. 2011: Evolutionary and Genetic Basis of Morphological Variation in Populus nigra (European black poplar). University Of Southampton, Faculty Of Natural \& Environmental Sciences, School of Biological Sciences. Doktorska disertacija. Str. 1-342.

- De Woody J., H. Trewin, G. Taylor, 2015: Genetic and morfological differentiation in Populus nigra L.: isolation by colonization or isolation by adaptation. Molecular ecology, 24: 26412655.

- Fukarek P. 1959: Pregled dendroflore Bosne i Hercegovine. Narodni šumar., Sarajevo 13. 5/6:263-286.

- Glaubitz J.C. 2004: CONVERT: A user-friendly program to reformat diploid genotypic data for commonly used population genetic software packages. Molecular Ecology Notes, 4: 309310.

- Gregorius H.R. 1974: On the concept of genetic distance between populations based on gene frequencies. Proceedings, Joint IUFRO Meeting S.02-04. Str. 17-22.

- Gregorius H.R. 1987: The relationship between the concept of genetic diversity and differentiation. Theoretical \& Applied Genetics, 74: 397-401.

- Heinze B. 1998a: PCR-based chloroplast DNA assays for the identification of native Populus nigra and introduced poplar hybrids in Europe. Forest Genetics 5 (1): 31-38.

- Heinze B. 1998b: Biochemical and molecular genetic methods available for the characterization of Populus nigra L. In: Turok J., Lefévre F., de Vries S., Alba N., Heinze B., Van Slycken J. (Compilers), Populus nigra Network. Report of the fourth meeting, 3-5 October 1997, Geraardsbergen, Belgium. International Plant Genetic Resources Institute, Rome. Str. 42-70.

- Herpka I. 1983: A survey of development and possibilities of growing: natural forests of poplars and willows, in: Poplars and Willows in Yugoslavia. Poplar Research Institute, Novi Sad. Str. 21-36.

- Janjić N. 1983: Dve nove hibridne polupiramidalne crne topole iz centralne Bosne (Two new semipyramidal hybrid black poplars from central Bosnia). Biosistematika, Beograd, vol. 9, No.1:15-27.

- Janjić N. 1984: Prilog poznavanju dlakavih svojti crne topole ( $P$. nigra L.) u Bosni i Hercegovini. Glas. Zem. Muz. BiH, Prir. Nauke, Sarajevo, 23:255-278. 
- Janjić N. 1990: Prilog sistematici bele topole (Populus alba L.) u Bosni i Hercegovini(A contribution to the systematics of Populus alba L. in Bosnia and Herzegovina). God. Biol. Inst. Univ., Sarajevo 42:45-56.

- Janjić N. 1992-1996: Pregled prirodnih i gajenih topola Bosne i Hercegovine (Conseptus of native and introduced poplars of Bosnia and Herzegovina). ANU BiH, Radovi LXXXIX, odjelj. prir.-mat. Nauka, Sarajevo, 26: 109-117.

- Jovanović B. 2000: Dendrologija, Univerzitetska štampa, Beograd, str.1-536.

- Kajba D., D. Ballian, M. Idžojtić, S. Bogdan, 2004: The differences among hairy and typical European black poplars and the possible role of the hairy type in relation to climatic changes. Forest Ecology and Management, Vol. 197, 1-3: 279-284.

- Kajba D., D. Ballian, B. Heinze, M. Idzojtic, S. Bogdan, 2004a: Populus nigra ssp. caudina and its importance for forest tree improvement and conservation of poplar genetic resources. IPC 2004 - Chile, 22nd session, International poplar commission, Santiago - Chile 28 november 9 december 2004. Str. 29. Santiago.

- Kajba D., D. Ballian, B. Heinze, M. Idžojtić, S. Bogdan, I. Katičić -Trupčević, 2005: Importance of Conservation of the Hairy Type of Populus nigra in the Changing Climatic and Environmental Conditions. In: Čolić Franekić J, Ugarković Đ (eds) Second Congress of Croatian Geneticists, Supetar, Croatia, 24-27 September 2005. Croatian Genetic Society, Zagreb, Croatia, Str. 90. Supetar.

- Kajba D., D. Ballian, M. Idžojtić, I. Poljak, 2015: Leaf Morphology Variation of Populus nigra L. in Natural Populations along the Rivers in Croatia and Bosnia and Herzegovina. SEEFOR 6 (1): 39-51. Zagreb.

- Kremer A., O. Ronce, J.J. Robledo-Arnuncio, F. Guillaume, G. Bohrer, R. Nathan, J.R. Bridle, R. Gomulkiewicz, E.K. Klein, K. Ritland, A. Kuparinen, S. Gerber, S. Schueler, 2012: Long-distance gene flow and adaptation of forest trees to rapid climate change. Ecology Letters, 15: 378-392.

- Larsen J.B. 1986: Das Tannensterben: Eine neue Hypothese zur Klärung des Hintergrundes dieser rätselhaften Komplexkrankheit der Weißtanne (Abies alba Mill.), Fortwissenschaflitches Centralblatt, Gottingen, 105 (5): 381-396.

- Legionnet A., F. Lefévre, 1996: Genetic variation of the riparian pioneer tree species Populus nigra L. I. Study of population structure based on isozymes. Heredity 77: 629-637.

- Lojo A., B. Balić, 2011: Prikaz površina šuma i šumskih zemljišta. In: Lojo A., Balić B., Hočevar M., Vojniković S. Višnjić Ć., Musić J., Delić S., Treštić T., Čabaravdić A., Gurda S., Ibrahimspahić A., Dautbašić M., Mujezinović O.: Stanje šuma i šumskih zemljišta u Bosni i Hercegovini nakon provedene Druge inventure šuma na velikim površinama u periodu 2006 do 2009 godine.str.34-48.

- Nei M. 1972: Genetic distance between populations. Amer. Nat. 106: 283-291.

- Peakall R., P.E. Smouse, 2012: GenAlEx 6.5: genetic analysis in Excel. Population genetic software for teaching and research-an update.Bioinformatics, 28: 2537-2539.

- Pritchard J.K., X. Wen, D. Falush, 2007: Documentation for structure software: Version 2.2. http://pritch.bsd.uchicago.edu/ software/structure22/readme.pdf.

- Pospišková M., I. Bartáková, 2004: Genetic diversity of the black poplar in the Morava river basin assessed by microsatellite analysis, Forest Genetics, 11 (3-4): 257-262.
- Rathmacher G., M. Niggemann, H. Wypukol, K. Gebhardt, B. Ziegenhagen, R. Bialozyt, 2009: Allelic ladders and reference genotypes for a rigorous standardization of poplar microsatellite data. Trees 23, 573-583.

- Smulders M.J.M., J. Van Der Schoot, P. Arens, B. Vosman, 2001: Trinucleotide repeat microsatellite markers for black poplar (Populus nigra L.). Mol. Ecol. Notes 1: 188-190.

- Sork V.L., F.W. Davis, R. Westfall, A. Flint, M. Ikegami, H. Wang, D. Grivet 2010: Gene movement and genetic association with regional climate gradients in California valley oak (Quercus lobata Née) in the face of climate change. Molecular Ecology, 19: 3806-3823.

- Stefanović V., V. Beus, Č. Burlica, H. Dizdarević, I. Vukorep, 1983: Ekološko-vegetacijska rejonizacija Bosne i Hercegovine. Šumarski fakultet, Posebna izdanja br. 17. Str. 1-51. Sarajevo.

- Šilić Č. 1983: Atlas drveća i grmlja, Sarajevo, Bosna i Hercegovina. Str. 1-218. Sarajevo.

- Tröber U., H. Wolf, 2015: Erhaltung der Schwarz-Pappel (Populus nigra L.) in Sachsen: Erfassung, Charakterisierung und Vermehrung auf genetischer Grundlage. Forstarchiv 86(6): 166173.

- Tuskan G.A., L.E. Gunter, Z.K. Yang, T. Yin, M.M. Sewell, S.P. Di Fazio, 2004: Characterization of microsatellites revealed by genomic sequencing of Populus trichocarpa. Canadian Journal of Forest Research 34:85-93.

- van Dam B.C. 2002: EUROPOP: Genetic Diversity in River Populations of European Black Poplar for evaluation of biodiversity, conservation strategies, nature development and genetic improvemen. In: Genetic diversity in river populations of European Black Poplar - implications for riparian eco-system management. (van Dam B. C., Bordács S. (Ed.)). Proceedings of an international symposium held in Szekszird, Hungary, 16-20 May, 2001. Str. 15-32. Szekszird.

- van der Schoot J., M. Pospišková, B. Vosman, M.J.M. Smulders, 2000: Development and characterization of microsatellite markers in black poplar (Populus nigra L.). Theoretical and Applied Genetics, 101:317-322.

- Vanden Broeck A. 2003: EUFORGEN Technical Guidelines for genetic conservation and use of European black poplar (Populus nigra). IPGRI, Rome, Italy, str. 1-6.

- Vanden Broeck A., K. Cox, J. Van Slycken, D. Halfmaerten, 2000: Genetic pollution and mating systems in an artificial stand of black poplar (Populus nigra L.). In: Isebrands JG, Richardson J (eds) 21st Session of the IPC-2000: poplar and willow culture: meeting the needs of society and the environment, Vancouver, Canada, 24-28 September 2000. US Department of Agriculture, Forest Service, North Central Research Station, Gen Tech Rep NC-215, St Paul, MN, USA. Str. 186. Vancouver.

- Winfield M.O., G.M. Arnold, F. Cooper, M. Le Ray, J. White, A. Karp, K.J. Edwards, 1998: A study of genetic diversity in Populus nigra subsp. betulifolia in the Upper Severn area of the UK using AFLP markers. Molecular ecology, 7: 3-10.

- Ziegenhagen B., S. Gneuss, G. Rathmacher, I. Leyer, R. Bialozyt, B. Heinze, S. Liepelt, 2008: A fast and simple survey reveals the spread of poplar hybrids at a natural Elbe river site. Conservation Genetics 9: 373-379

- Zsuffa L. 1974 The genetics of Populus nigra L. Annales Forestales, 6 (2): 29-53. 


\section{Summary}

European black poplar represents one of the ecologically most important tree species of alluvial forest association. In some countries, the potential of this species for forest management is significant. As in most countries of central Europe they have been drawn back in Bosnia and Herzegovina in the past and this has remained to date. In the present conditions in $\mathrm{BiH}$, there is a potential to established and grow poplar forests on areas of 40,000ha, in small pure units and mainly mixed with willow and other hydrophilic species. As a peculiarity in $\mathrm{BiH}$, beside black poplar there is a population of hairy black poplar (P. nigra subsp. caudina). To protect the genetic resources of Populus nigra in $\mathrm{BiH}$, a clonal archive with 163 clones selected in several autochthonous localities has been established at the location Žepče. In total 141 of these clones were sampled for genotyping with 10 microsatellite markers. According to their origin, they were assigned to 11 populations with respect to the catchment areas of the main rivers.

The aim of the study is to describe genetic structure, diversity and differentiation of populations of black poplar from the river deltas in $\mathrm{BiH}$, and to emphasize the importance of knowledge of these structures in the processes of regeneration and conservation of this species.

Sample sizes of the populations are in general very small, they reach from seven with only three different genotypes (upper stream of Vrbas river) to 20 with 19 genotypes (in upper stream Bosna river). Consequently, the number of detected alleles over 10 loci is lowest in population upper stream Vrbas with 29 and highest in upper stream Bosna river with 81 alleles.

Beside population upper stream Vrbas with only three genotypes, low values of genetic multiplicity and lowest values of genetic diversity shows population lower stream Neretva, although represented by 14 multilocus genotypes. The observed as well as the expected heterozygosity are much lower in this population than in all other populations, too. This special structure might occur due to its isolated location and the fact, that this is the population with the hairy black poplars. By means of cluster analysis, it is demonstrated that the genetic structures of this population apparently differs from the others, but differences between the river populations are also indicated.

The parameters of genetic variation of all other populations are in a similar range. The values of genetic distance and differentiation between populations show, that differences between the populations from the same river are on average smaller than between populations from different rivers and that the three populations from the river Bosna represent the gene pool of black poplar in $\mathrm{BiH}$ best. After exclusion of the two extreme populations, a principal coordinate analysis based on genetic distances illustrates that more clearly.

These results can be used as a basis for planning and realization of measures for the conservation of the genetic resources of black poplar in Bosnia and Herzegovina. 